Published in final edited form as:

J Nat Prod. 2007 June ; 70(6): 1064-1067.

\title{
Antiproliferative Cardenolides of an Elaeodendron sp. from the Madagascar Rain Forest
}

\author{
Shugeng Cao $†$, Peggy J. Brodie $†$, James S. Miller $\ddagger$, Fidy Ratovoson $\S$, Martin W. \\ Callmander ${ }^{\S}$, Sennen Randrianasolo ${ }^{\perp}$, Etienne Rakotobe ${ }^{\perp}$, Vincent E. Rasamison ${ }^{\perp}$, Edward \\ M. Suh $\|$, Karen TenDyke $\|$, and David G. I. Kingston $\dagger^{\star}$ \\ Department of Chemistry, M/C 0212, Virginia Polytechnic Institute and State University, Blacksburg, \\ Virginia 24061, Missouri Botanical Garden, P. O. Box 299, St. Louis, Missouri 63166-0299, and B.P \\ 3391, Antananarivo, Madagascar, and Centre National d'Application des Recherches \\ Pharmaceutiques, B. P. 702, Antananarivo 101, Madagascar, and Eisai Research Institute, 4 \\ Corporate Drive, Andover, MA 01810
}

\begin{abstract}
Bioassay-guided fractionation of an ethanol extract obtained from the Madagascar plant Elaeodendron sp. led to the isolation of two new cardenolides, elaeodendrosides $\mathrm{T}$ and $\mathrm{U}$ (1 and $\mathbf{2}$ ). The structures of the new compounds were elucidated using 1D and 2D NMR experiments, and mass spectrometry. Compounds $\mathbf{1 , 3 , 4}$, and $\mathbf{5}$ showed significant antiproliferative activity against A2780 human ovarian cancer cells with $\mathrm{IC}_{50}$ values of $0.085,0.019,0.19$, and $0.10 \mu \mathrm{M}$, respectively, while compounds $\mathbf{2}$ and $\mathbf{6}$ were less active.
\end{abstract}

In our continuing search for bioactive molecules from the Madagascar rainforests as part of an International Cooperative Biodiversity Group (ICBG) program, ${ }^{1}$ we obtained an EtOH extract of the wood of Elaeodendron sp. (Celastraceae). This extract (MG 3232) showed antiproliferative activity against the A2780 ovarian cancer cell line with an $\mathrm{IC}_{50}$ value of 7.6 $\mu \mathrm{g} / \mathrm{mL}$. The extract was selected for bioassay-guided fractionation based on its activity, and also on the absence of any previous chemical investigation of the species.

There are ca. forty species in the genus Elaeodendron from the Mexican coast, Bermuda, Africa, Madagascar (incl. Mascarene), India, Melanesia, and Australia. ${ }^{2}$ The plants in this genus are usually glabrous trees or shrubs, ${ }^{2}$ and flavonoids, ${ }^{3}$ terpenoids, ${ }^{4}$ and cardenolides ${ }^{5}$ have been isolated from them. Cardenolides are also prominent cardioactive secondary metabolites of many medicinal plants belonging to the Apocynaceae (Nerium, Strophanthus, Thevetia), Asclepiadaceae (Periploca, Calotropis, Xysmalobium), Scrophulariaceae (Digitalis), Ranunculaceae (Adonis), and Convallariaceae families (Convallaria, Speirantha). 6 The cytotoxicity of cardenolides as well as their cardiac activity have been widely studied. 7

An EtOH extract of the woods (MG 3232) of Elaeodendron sp. was subjected to liquid-liquid partitioning to give an active $\mathrm{CH}_{2} \mathrm{Cl}_{2}$ fraction with an $\mathrm{IC}_{50}$ value of $0.3 \mu \mathrm{g} / \mathrm{mL}$ in the A2780

\footnotetext{
*To whom correspondence should be addressed. Tel: (540) 231-6570. Fax: (540) 231-7702. E-mail: dkingston@ vt.edu.

$\dagger$ Virginia Polytechnic Institute and State University.

\$ Missouri Botanical Garden, St. Louis; current address: The New York Botanical Garden, 200th St. \& Kazimiroff Blvd., Bronx, NY 10458-5126.

\$Missouri Botanical Garden, Antananarivo.

Centre National d'Application des Recherches Pharmaceutiques.

"Eisai Research Institute.

Supporting Information Available: ${ }^{1} \mathrm{H}$ and ${ }^{13} \mathrm{C}$ NMR spectra of compounds 1 and 2 . This material is available free of charge via the Internet at http://pubs.acs.org.
} 
assay. Activity-guided separation of this fraction by passage over a $\mathrm{C}_{18} \mathrm{SPE}$ column yielded three subfractions, and subjection of the active second subfraction to further purification using $\mathrm{C}_{18}$ HPLC led to the isolation of the two new compounds $\mathbf{1}$ and $\mathbf{2}$, and the four known compounds elaeodendroside $B(3), 5 f$ elaeodendroside $F(4), 5 f$ elaeodendroside $G(5), 5 f$ and $(2 \alpha, 3 \beta, 14 \beta)$-trihydroxy-3-O-(4-deoxy-3-O-methyl- $\alpha$-L-erythro-pentopyranosyl)-card-4,20 (22)-dienolide (6). ${ }^{5 \mathrm{~g}}$ Here we report the structures of the two new compounds elaeodendroside $\mathrm{T}(\mathbf{1})$ and $\mathrm{U}(\mathbf{2})$ as well as the antiproliferative activity of all the isolates.

Compound 1 was obtained as a white powder. Its HRFABMS (positive-ion mode) exhibited a quasimolecular ion peak at $\mathrm{m} / \mathrm{z} 589.2962$, consistent with a molecular composition of $\mathrm{C}_{32} \mathrm{H}_{45} \mathrm{O}_{10}$ (calcd 589.3013). The ${ }^{13} \mathrm{C}$ NMR spectrum of compound $\mathbf{1}$ contained 32 signals, which were assigned to one methoxy, one acetoxy, three methyls, eight methylenes, eleven methines, and eight quaternary carbons based on its ${ }^{1} \mathrm{H}$ NMR and HSQC spectra. The ${ }^{1} \mathrm{H}$ and ${ }^{13} \mathrm{C}$ NMR signals $\left(\mathrm{C}_{6} \mathrm{D}_{6}\right.$, Table 1$)$ at $\delta_{\mathrm{C}} 170.3(\mathrm{C}-20), \delta_{\mathrm{C}} / \delta_{\mathrm{H}} 73.3(\mathrm{C}-21) / 4.71$ and 4.56 (both as br d, $\left.J=17.9 \mathrm{~Hz}, \mathrm{H}_{2}-21\right), \delta_{\mathrm{C}} / \delta_{\mathrm{H}} 119.0(\mathrm{C} 22) / 5.85$ (br s, H22), and $\delta_{\mathrm{C}} 173.4$ (C23), indicated the presence of an $\alpha, \beta$-unsaturated $\gamma$-lactone unit. The spin systems in ring $\mathrm{A}\left(\mathrm{H}_{2}-1\right.$ through $\mathrm{H}-2$ and $\mathrm{H}-3$ to $\mathrm{H}-4$ : $\left.\mathrm{CH}_{2}-\mathrm{CH}-\mathrm{CH}-\mathrm{CH}\right)$, rings $\mathrm{B}$ and $\mathrm{C}\left(\mathrm{H}_{2}-6\right.$ through $\mathrm{H}_{2}-7, \mathrm{H}-8$, $\mathrm{H}-9$, and $\mathrm{H}_{2}-11$ to $\left.\mathrm{H}_{2}-12: \mathrm{CH}_{2}-\mathrm{CH}_{2}-\mathrm{CH}-\mathrm{CH}-\mathrm{CH}_{2}-\mathrm{CH}_{2}\right)$, and ring $\mathrm{D}\left(\mathrm{H}_{2}-15\right.$ through H-16 to $\mathrm{H}-17: \mathrm{CH}_{2}-\mathrm{CH}-\mathrm{CH}$ ) of the aglycone were identified from the COSY and TOSCY spectra. The aglycone of $\mathbf{1}$ was established as a 2,3,14,16-tetraoxygenated card-4,20(22)dienolide based on its HMBC correlations (Fig. 1). The acetoxy group attached to C-16 was detected by HMBC correlations from both $\mathrm{H}-16\left(\delta_{\mathrm{H}} 5.15\right.$, ddd, $\left.J=11.3,7.7,4.1 \mathrm{~Hz}\right)$ and the methyl protons of the acetyl group $\left(\delta_{\mathrm{H}} 1.70, \mathrm{~s}\right)$ to the carbonyl carbon at $\delta_{\mathrm{C}} 169.8$. H-3 showed a ROESY correlation (Fig. 2) to $\mathrm{H}_{\alpha^{-}}$(axial-like), and $\mathrm{H}-2$ exhibited ROESY correlations to $\mathrm{H}_{3}-19$ and $\mathrm{H}_{\beta}-1$ (equatorial-like), indicating a trans relationship between $\mathrm{H}-3$ and $\mathrm{H}-2$. The trans and cis fusions for the rings $\mathrm{B} / \mathrm{C}$ and $\mathrm{C} / \mathrm{D}$ were established by the ROESY correlations from $\mathrm{H}_{\alpha^{-1}}$ (axial-like) to $\mathrm{H}-9$, from $\mathrm{H}-15$ to $\mathrm{H}-7$, and from both $\mathrm{H}_{3}-18$ and $\mathrm{H}_{3}-19$ to $\mathrm{H}_{\beta}-11$ (axial) and $\mathrm{H}-8$, separately. The ROESY spectrum of $\mathbf{1}$ also revealed crosspeaks from $\mathrm{H}-17$ to $\mathrm{H}-21, \mathrm{H}-22$, and $\mathrm{H}-16$, and from $\mathrm{H}_{3}-18$ to $\mathrm{H}-21$ and $\mathrm{H}-22$; the substituents at 13-, 16-, and 17positions were therefore designated $\beta$. The multiplicities and coupling constants of the protons in the sugar moiety were deduced from the ${ }^{1} \mathrm{H}$ NMR spectrum as follows: $\mathrm{H}-1^{\prime}$ showed a singlet at $\delta 5.04 ; \mathrm{H}-3^{\prime}$ appeared as a broad singlet at $\delta 3.29 ; \mathrm{H}_{2}-4^{\prime}$ resonated as two multiplets at $\delta 1.53$ and $1.80 ; \mathrm{H}-5^{\prime}$ appeared as a multiplet at $\delta 3.90 ; \mathrm{H}_{3}-6^{\prime}$ resonated as a doublet at $\delta 1.22(\mathrm{~J}=5.2$ $\mathrm{Hz}$ ) while the $3^{\prime}-\mathrm{OMe}$ resonated at $\delta 2.90$ as a singlet. The connectivity of protons in ring A' $\left(\mathrm{H}-3^{\prime}\right.$ through $\mathrm{H}_{2}-4^{\prime}$ and $\mathrm{H}^{\prime} 5^{\prime}$, to $\mathrm{H}_{3}-6^{\prime}$ : $\left.\mathrm{CH}-\mathrm{CH}_{2}-\mathrm{CH}-\mathrm{CH}_{3}\right)$ was confirmed by the $\mathrm{COSY}$ and TOCSY spectra. ROESY correlations from $\mathrm{H}-1^{\prime}$ to $2^{\prime}-\mathrm{OH}(\delta 3.61)$, and from $\mathrm{H}-5^{\prime}$ to $\mathrm{H}-1^{\prime}$ and 3'-OMe indicated that the sugar moiety was a 2'-oxygenated 4',6'-dideoxy-3'-O-methylallopyranoside. The connectivity between $\mathrm{C}-1^{\prime}$ and $\mathrm{C}-3$ through an oxygen bridge was confirmed by the observation of an HMBC correlation from $\mathrm{H}-1$ ' to $\mathrm{C}-3$.

In order to determine the orientation of the hydroxyl groups at the 14- and 2'-positions, NMR data were collected in DMSO- $d_{6}\left({ }^{1} \mathrm{H}\right.$ NMR data, Experimental Section; ${ }^{13} \mathrm{C}$ NMR data, Table 1). The 14-OH proton $\left(\delta_{\mathrm{H}} 4.59, \mathrm{~s}\right)$ showed ROESY correlations to $\mathrm{H}-18\left(\delta_{\mathrm{H}} 0.78, \mathrm{~s}\right), \mathrm{H}-8$ $\left(\delta_{\mathrm{H}} 1.57\right)$, and $\mathrm{H}-15\left(\delta_{\mathrm{H}} 2.06\right)$, which confirmed a cis fusion of rings C/D. ROESY correlations from $2^{\prime}-\mathrm{OH}\left(\delta_{\mathrm{H}} 6.12, \mathrm{~s}\right)$ to $\mathrm{H}-1^{\prime}\left(\delta_{\mathrm{H}} 4.54, \mathrm{~s}\right), \mathrm{H}-3^{\prime}\left(\delta_{\mathrm{H}} 3.15\right.$, br s), and $\mathrm{H}-2\left(\delta_{\mathrm{H}} 4.06\right.$, ddd, $J=$ $2.8,8.5,12.1 \mathrm{~Hz}$ ) supported the presence of another oxygen bridge from $\mathrm{C}-2^{\prime}$ to $\mathrm{C}-2$, which formed a 1,4-dioxane ring in the chair conformation between rings $\mathrm{A}$ and $\mathrm{A}^{\prime}$. Furthermore, the ${ }^{13} \mathrm{C}$ NMR chemical shifts of the carbons in rings $\mathrm{A}^{\prime}, \mathrm{A}$ and $\mathrm{B}$ of $\mathbf{1}$ were close to those of affinoside $\mathrm{F}(7),{ }^{8}$ while the carbons in rings $\mathrm{C}, \mathrm{D}$, and $\mathrm{E}$ had similar chemical shifts to those of cryptostigmin II (8). ${ }^{9}$ The structure of $\mathbf{1}$ was thus established as indicated; it was given the trivial name elaeodendroside $\mathrm{T}$. 
Compound 2 was also obtained as a white powder. The molecular formula $\mathrm{C}_{29} \mathrm{H}_{40} \mathrm{O}_{9}$ of $\mathbf{2}$ was deduced from its HRFABMS. Its ${ }^{1} \mathrm{H}$ NMR spectral data $\left(\mathrm{C}_{6} \mathrm{D}_{6}\right.$, Table 1$)$ showed signals for a cardenolide framework, with methylene protons at $\delta_{\mathrm{H}} 4.27$ and $4.39\left(\mathrm{H}_{2}-21\right.$, d each, $J=17.9$ $\mathrm{Hz})$, an olefinic proton at $\delta_{\mathrm{H}} 5.79(\mathrm{H}-22, \mathrm{br} s)$ and a methine proton at $\delta_{\mathrm{H}} 3.97(\mathrm{H}-17, \mathrm{dd}, J=$ 8.6, 9.4 Hz). The methyl doublet and acetyl methyl present in 1 were absent in the ${ }^{1} \mathrm{H}$ NMR spectrum of 2 . The ${ }^{13} \mathrm{C}$ NMR (DMSO- $d_{6}$, Table 1 ) spectrum exhibited 29 signals comprised of one methoxy, two methyls, nine methylenes, ten methines, and seven quaternary carbons, which were assigned from its HSQC spectrum. The HMBC spectrum of 2 (Fig. 3) showed key correlations which established the location of the carbonyl group at C-12 and the sugar at C-3. The aglycone of 2 was thus established as a 2,3,14-trioxygenated 12-oxo-card-4,20(22)dienolide, which was the same as that of elaeodendroside $\mathrm{R} .5 \mathrm{~h}$ The orientation of $\mathrm{H}-2(\beta$, axiallike) and $\mathrm{H}-3$ ( $\alpha$, axial-like) of $\mathbf{2}$ were the same as those of $\mathbf{1}$ because $\mathrm{H}-2\left(\delta_{\mathrm{H}} 3.90\right)$ and $\mathrm{H}-3$ $\left(\delta_{\mathrm{H}} 3.90\right)$ showed ROESY (Fig. 4) correlations to $\mathrm{H}_{3}-19\left(\delta_{\mathrm{H}} 0.64\right)$ and $2-\mathrm{OH}\left(\delta_{\mathrm{H}} 4.54\right)$, respectively $\left(\mathrm{C}_{6} \mathrm{D}_{6}\right.$, Table 1$)$, which was also supported by the multiplicity of $\mathrm{H}-3\left(\delta_{\mathrm{H}} 3.92, \mathrm{~d}\right.$, $J=8.0 \mathrm{~Hz}$ ) in DMSO- $d_{6}$ (Experimental Section). The COSY and TOCSY data for 2 identified a connectivity sequence indicative of a coupling system in the sugar moiety $\left(\mathrm{H}-1^{\prime}\right.$ through $\mathrm{H}-2^{\prime}$, H-3', and $\mathrm{H}_{2}-4^{\prime}$, to $\mathrm{H}_{2}-5^{\prime}$ : $\mathrm{CH}-\mathrm{CH}-\mathrm{CH}-\mathrm{CH}_{2}-\mathrm{CH}_{2}$ ). A small coupling constant of $\mathrm{H}-1^{\prime}$ at $\delta_{\mathrm{H}} 4.65\left(\mathrm{~d}, J=3.3 \mathrm{~Hz}, \mathrm{C}_{6} \mathrm{D}_{6}\right.$, Table 1$)$ indicated that $\mathrm{H}^{\prime}$ was equatorial. ROESY crosspeaks from $\mathrm{H}-1^{\prime}$ to $\mathrm{H}-3^{\prime}$, and from $\mathrm{H}-2^{\prime}$ to $\mathrm{H}-3^{\prime}$ and $3^{\prime}-\mathrm{OMe}$ suggested $\mathrm{H}-3^{\prime}$ was axial. These considerations established the structure of $\mathbf{2}$ as indicated, and it was given the trivial name elaeodendroside $\mathrm{U}$.

Compounds 1-6 were tested for antiproliferative activity against the A2780 human ovarian cancer cell line, and the two most active compounds $\mathbf{1}$ and $\mathbf{3}$ were also evaluated against four additional cell lines. The results are shown in Table 2. The assay results demonstrate that the 1,4-dioxane rings between rings $\mathrm{A}$ and $\mathrm{A}^{\prime}$ in compounds $\mathbf{1 , 3}, \mathbf{4}$, and $\mathbf{5}$ are important for their antiproliferative activity, since compounds $\mathbf{2}$ and $\mathbf{6}$ lacking this structural feature are significantly less active than the compounds with this feature.

\section{Experimental Section}

\section{General Experimental Procedures}

Optical rotations were recorded on a Perkin-Elmer 241 polarimeter. IR spectra were measured on a MIDAC M-series FTIR spectrophotometer. NMR spectra were obtained on a JEOL Eclipse 500 and an Inova 400 spectrometer. The chemical shifts are given in $\delta(\mathrm{ppm})$, and coupling constants are reported in Hz. Mass spectra were obtained on a JEOL JMS-HX-110 instrument, in the positive ion mode. HPLC was performed on a Shimadzu LC-10AT instrument with a semi-preparative $\mathrm{C}_{8}$ Varian Dynamax column $(5 \mu \mathrm{m}, 250 \times 10 \mathrm{~mm})$ and a preparative $\mathrm{C}_{18}$ Varian Dynamax column $(8 \mu \mathrm{m}, 250 \times 21.4 \mathrm{~mm})$.

\section{Antiproliferative Activity}

Determinations of antiproliferative activities were performed at Virginia Polytechnic Institute and State University against the A2780 ovarian cancer cell line as previously described. ${ }^{10}$ The A2780 cell line is a drug - sensitive human ovarian cancer cell line. ${ }^{11}$ Antiproliferative effects of compounds on the four cultured human cancer cell lines MDA-MB-435 breast cancer, HT-29 colon cancer, H522-T1 non-small cell cancer, and U937 histiocytic lymphoma were performed at Eisai Research Institute as previously described, ${ }^{12}$ with the exception that luminescence was read on an Envision 2102 Multilabel Reader.

\section{Plant Material}

Wood of the tree Elaeodendron sp. (Celastraceae) was collected in the Montagne des Français region, a dry forest on limestone, Antsiranana, Madagascar, at elevation: $220 \mathrm{~m}$, at 12.24 .42 
S, 49.22.22 E, on February 14, 2005. The tree was $14 \mathrm{~m}$ high with diameter at breast height of $55 \mathrm{~cm}$, growing on a boulder near a stream, and it yellow petioles, red bark, red wood, gray stem, and immature green fruit. It was determined by R. H. Archer (South African National Biodiversity Institute) in 2007 as a new species; its assigned collector number is Randrianasolo.S (SSR) 520. The species of Elaeodendron collected in Madagascar is different from E. orientale Jacq., the type of the genus, known only from the Mascarene Islands. It has similar leaves, but the fruit is much smaller with sharp points at both ends. In addition, juvenile leaves are conspicuously long and narrow. The vernacular of the new species is tangenala. Species of Cerbera (Apocynaceae) with the same vernacular name were formerly used for the ordeal by poison practice in Madagascar. Nothing is known about the uses of Elaeodendron except that the fruit is reported to be toxic to lemurs. Voucher specimens have been deposited at herbaria of: the Centre National d'Application des Recherches Pharmaceutiques, Madagascar (CNARP); the Parc Botanique et Zoologique de Tsimbazaza, Madagascar (TAN); at the Missouri Botanical Garden, St. Louis, Missouri (MO); and at the Muséum National d'Histoires Naturelles, Paris, France (P).

\section{Extraction and Isolation}

Dried wood of Elaeodendon sp. $(250 \mathrm{~g})$ were ground in a hammer mill, then extracted with EtOH by percolation for $24 \mathrm{~h}$ at rt to give the crude extract MG $3232(15.9 \mathrm{~g})$, of which $5.0 \mathrm{~g}$ was shipped to Virginia Polytechnic Institute and State University (VPISU) for fractionation. MG $3232(1.5 \mathrm{~g})$ was suspended in aqueous $\mathrm{MeOH}\left(\mathrm{MeOH}-\mathrm{H}_{2} \mathrm{O}, 9: 1,150 \mathrm{~mL}\right)$ and extracted with hexanes $(3 \times 150 \mathrm{~mL}$ portions). The aqueous layer was then diluted to $70 \% \mathrm{MeOH}(\mathrm{v} / \mathrm{v})$ with $\mathrm{H}_{2} \mathrm{O}$ and extracted with $\mathrm{CH}_{2} \mathrm{Cl}_{2}(3 \times 160 \mathrm{~mL}$ portions $)$. The $\mathrm{CH}_{2} \mathrm{Cl}_{2}$ extract was evaporated in vacuo to leave a $128.8 \mathrm{mg}$ of residue $\left(\mathrm{IC}_{50}: 0.3 \mu \mathrm{g} / \mathrm{mL}\right)$. Both the hexane and aqueous $\mathrm{MeOH}$ extracts ( $40.3 \mathrm{mg}$ and $1.3 \mathrm{~g}$ ) were inactive. The $\mathrm{CH}_{2} \mathrm{Cl}_{2}$ extract was treated with $\mathrm{C}_{18}$ SPE eluting with $50 \%$, then $100 \% \mathrm{MeOH}-\mathrm{H}_{2} \mathrm{O}$, and $5 \% \mathrm{CH}_{2} \mathrm{Cl}_{2}-\mathrm{MeOH}$ to furnish three fractions (I-III: 25,100 , and $3 \mathrm{mg}$, respectively). Only fraction II was active with an $\mathrm{IC}_{50}$ value of $0.3 \mu \mathrm{g} / \mathrm{mL}$, and this fraction was loaded on a $\mathrm{C}_{18}$ Varian Dynamax HPLC column [ $8 \mu \mathrm{m}, 250 \times 21.4 \mathrm{~mm}, 10 \mathrm{~mL} / \mathrm{min}\left(0 \mathrm{~min}, 18 \mathrm{~min}, 40 \mathrm{~min} ; 50 \%, 56 \%, 100 \% \mathrm{MeOH}-\mathrm{H}_{2} \mathrm{O}\right)$ ], and thirteen subfractions (A-M) were collected. Subfractions J, K and L yielded compounds $5\left(3 \mathrm{mg}, t_{\mathrm{R}} 35.5 \mathrm{~min}\right), \mathbf{6}\left(1 \mathrm{mg}, t_{\mathrm{R}} 38.5 \mathrm{~min}\right)$ and $\mathbf{1}\left(2 \mathrm{mg}, t_{\mathrm{R}} 49 \mathrm{~min}\right)$, respectively. Purification of subfraction $\mathrm{E}$ was carried out by $\mathrm{C}_{8} \mathrm{HPLC}$ with $45 \% \mathrm{MeOH}-\mathrm{H}_{2} \mathrm{O}$ as an eluent to yield 2 $\left(0.5 \mathrm{mg}, t_{\mathrm{R}} 24 \mathrm{~min}\right)$. Subfraction $\mathrm{H}$ yielded compound $\mathbf{3}\left(1.2 \mathrm{mg}, R_{f} 0.30\right)$ and compound $\mathbf{4}$ (1.1 $\left.\mathrm{mg}, R_{f} 0.35\right)$ after separation over preparative $\mathrm{Si}$ gel TLC developed with $\mathrm{CH}_{2} \mathrm{Cl}_{2}-\mathrm{MeOH}$ $(20: 1)$.

\section{Elaeodendroside T. (1)}

white powder; $[\alpha]_{\mathrm{D}}^{23}+12(c 0.05, \mathrm{MeOH}) ; \mathrm{UV}(\mathrm{MeOH}) \lambda_{\max }(\log \varepsilon) 218(4.39) \mathrm{nm}$; IR (film) $v_{\max } 3430,2930,1733,1448,1373,1242,1091,1027 \mathrm{~cm}^{-1} ;{ }^{1} \mathrm{H}$ NMR $(500 \mathrm{MHz}$, DMSO$\left.d_{6}\right): 0.78\left(3 \mathrm{H}, \mathrm{s}, \mathrm{H}_{3} 18\right), 0.87(1 \mathrm{H}, \mathrm{t}, J=12.1 \mathrm{~Hz}, \mathrm{H} 7 \mathrm{a}), 1.04\left(3 \mathrm{H}, \mathrm{s}, \mathrm{H}_{3} 19\right), 1.11(3 \mathrm{H}, \mathrm{d}, J=5.0$ $\left.\mathrm{Hz}, \mathrm{H}_{3} 6^{\prime}\right), 1.19(1 \mathrm{H}, \mathrm{t}, J=11.3 \mathrm{~Hz}, \mathrm{H} 9), 1.23(1 \mathrm{H}, \mathrm{t}, J=13.0 \mathrm{~Hz}, \mathrm{H} 11 \mathrm{a}), 1.38(1 \mathrm{H}, \mathrm{dd}, J=$ 12.1, $12.4 \mathrm{~Hz}, \mathrm{H} 1 \mathrm{a}), 1.50(1 \mathrm{H}, \mathrm{m}, \mathrm{H} 11 \mathrm{~b}), 1.55(1 \mathrm{H}, \mathrm{m}, \mathrm{H} 4 \mathrm{a}), 1.57(1 \mathrm{H}, \mathrm{m}, \mathrm{H} 8), 1.58(1 \mathrm{H}, \mathrm{m}$, H12a), 1.61 (1H, dd, $J=2.8,12.4 \mathrm{~Hz}, \mathrm{H} 1 \mathrm{~b}), 1.75\left(1 \mathrm{H}, \mathrm{dd}, J=2.0,13.8 \mathrm{~Hz}, \mathrm{H} 4 \mathrm{~b}^{\prime}\right), 1.98$ (3H, s, 16-OAc), $2.06\left(2 \mathrm{H}, \mathrm{m}, \mathrm{H}_{2} 6\right), 2.06(1 \mathrm{H}, \mathrm{m}, \mathrm{H} 7 \mathrm{~b}), 2.06(1 \mathrm{H}, \mathrm{m}, \mathrm{H} 12 \mathrm{~b}), 2.06\left(2 \mathrm{H}, \mathrm{m}, \mathrm{H}_{2} 15\right)$, $2.68(1 \mathrm{H}, \mathrm{d}, J=3.8 \mathrm{~Hz}, \mathrm{H} 17), 3.15\left(1 \mathrm{H}, \mathrm{br} \mathrm{s}, \mathrm{H} 3{ }^{\prime}\right), 3.83\left(1 \mathrm{H}, \mathrm{m}, \mathrm{H} 5^{\prime}\right), 4.06(1 \mathrm{H}$, ddd, $J=2.8$, $8.5,12.1 \mathrm{~Hz}, \mathrm{H} 2), 4.37(1 \mathrm{H}, \mathrm{d}, J=8.5 \mathrm{~Hz}, \mathrm{H} 3), 4.54\left(1 \mathrm{H}, \mathrm{s}, \mathrm{H} 1^{\prime}\right), 4.59(1 \mathrm{H}, \mathrm{s}, 14-\mathrm{OH}), 4.89$ $\left(2 \mathrm{H}\right.$, br s, $\left.\mathrm{H}_{2} 21\right), 5.08(1 \mathrm{H}, \mathrm{br} \mathrm{s}, \mathrm{H} 4), 5.14(1 \mathrm{H}, \mathrm{ddd}, J=3.8,8.0,12.1 \mathrm{~Hz}, \mathrm{H} 16), 5.98(1 \mathrm{H}, \mathrm{s}$, $\mathrm{H} 22), 6.12\left(1 \mathrm{H}, \mathrm{s}, 2^{\prime}-\mathrm{OH}\right) ;{ }^{1} \mathrm{H}$ NMR $\left(500 \mathrm{MHz}, \mathrm{C}_{6} \mathrm{D}_{6}\right)$ and ${ }^{13} \mathrm{C} \mathrm{NMR}\left(125 \mathrm{MHz}, \mathrm{C}_{6} \mathrm{D}_{6}\right.$ and DMSO- $d_{6}$ ) see Table 1 ; HRFABMS $m / z 589.2962$ (calcd for $\mathrm{C}_{32} \mathrm{H}_{45} \mathrm{O}_{10}$, 589.3013). 


\section{Elaeodendroside U. (2)}

white powder; $[\alpha]_{\mathrm{D}}^{23}$-9 $(c 0.11, \mathrm{MeOH}) ; \mathrm{UV}(\mathrm{MeOH}) \lambda_{\max }(\log \varepsilon) 220$ (4.01) nm; IR (film) $v_{\max } 3434,2938,1736,1445,1370,1240,1067 \mathrm{~cm}^{-1} ;{ }^{1} \mathrm{H}$ NMR $\left(500 \mathrm{MHz}\right.$, DMSO- $\left.d_{6}\right): 0.98$ ( $\left.3 \mathrm{H}, \mathrm{s}, \mathrm{H}_{3} 18\right), 1.08$ (3H, s, $\left.\mathrm{H}_{3} 19\right), 3.24$ (3H, s, 3'-OMe), 3.30 (1H, m, H3'), 3.35 (1H, m, H5a'), $3.53(1 \mathrm{H}, \mathrm{m}, \mathrm{H} 2), 3.79\left(1 \mathrm{H}, \mathrm{br} \mathrm{s}, \mathrm{H} 2^{\prime}\right), 3.86\left(1 \mathrm{H}, \mathrm{m}, \mathrm{H} 5 \mathrm{~b}^{\prime}\right), 3.92(1 \mathrm{H}, \mathrm{d}, J=8.0 \mathrm{~Hz}, \mathrm{H} 3), 3.99$ $(1 \mathrm{H}, \mathrm{dd}, J=8.0,8.3 \mathrm{~Hz}, \mathrm{H} 17), 4.45\left(1 \mathrm{H}, \mathrm{s}, \mathrm{H} 1^{\prime}\right), 4.90\left(2 \mathrm{H}, \mathrm{br} \mathrm{s}, \mathrm{H}_{2} 21\right), 5.25(1 \mathrm{H}, \mathrm{s}, \mathrm{H} 4), 5.96$ $(1 \mathrm{H}, \mathrm{s}, \mathrm{H} 22) ;{ }^{1} \mathrm{H}$ NMR $\left(500 \mathrm{MHz}, \mathrm{C}_{6} \mathrm{D}_{6}\right)$ and ${ }^{13} \mathrm{C}$ NMR $\left(125 \mathrm{MHz}\right.$, DMSO- $\left.d_{6}\right)$ see Table 1 ; HRFABMS m/z 555.2528 (calcd for $\mathrm{C}_{29} \mathrm{H}_{40} \mathrm{O}_{9} \mathrm{Na}, 555.2570$ ).

\section{Supplementary Material}

Refer to Web version on PubMed Central for supplementary material.

\section{Acknowledgment}

This project was supported by the Fogarty International Center, the National Cancer Institute, the National Science Foundation, the National Heart, Lung and Blood Institute, the National Institute of Mental Health, the Office of Dietary Supplements, and the Office of the Director of NIH, under Cooperative Agreement U01 TW 00313 with the International Cooperative Biodiversity Groups, and this support is gratefully acknowledged. We thank Mr. B. Bebout for obtaining the mass spectra, Mr. T. Glass for assistance with the NMR spectra and Dr. R. H. Archer at the National Herbarium, South African National Biodiversity Institute, Pretoria for data on the genus Elaeodendron. Field work essential for this project was conducted under a collaborative agreement between the Missouri Botanical Garden and the Parc Botanique et Zoologique de Tsimbazaza and a multilateral agreement between the ICBG partners, including the Centre National d'Applications des Recherches Pharmaceutiques. We gratefully acknowledge courtesies extended by the Government of Madagascar (Ministère des Eaux et Forêts).

\section{References and Notes}

1. Biodiversity Conservation and Drug Discovery in Madagascar, Part 28. For Part 27, see: Cao S, Brodie PJ, Miller JS, Ratovoson F, Birkinshaw C, Randrianasolo S, Rakotobe E, Rasamison VE, Kingston DGI. J. Nat. Prod. 2007

2. (a) Archer RH, Van Wyk AE. S. Afr. J. Bot 1998;64:93-109. (b) Islam MB, Simmons MP, Archer RH. Syst. Bot 2006;31:512-524.

3. (a) Weeratunga G, Bohlin L, Sandberg F, Kumar V. Acta Pharm. Suecica 1984;21:73-76. (b) Weeratunga G, Bohlin L, Verpoorte R, Kumar V. Phytochemistry 1985;24:2093-2095.

4. (a) Anjaneyulu ASR, Narayana Rao M. Phytochemistry 1980;19:1163-1169. (b) Weeratunga G, Kumar V, Sultanbawa MUS, Balasubramaniam S. J. Chem. Soc., Perkin Trans. 1: Org. Bioorg. Chem 1982:2457-2459. (c) Weeratunga G, Kumar V, Sultanbawa MUS. Tetrahedron Lett 1982;23:20312032. (d) Weeratunga G, Kumar V, Sultanbawa MUS. Aust. J. Chem 1983;36:1067-1072. (e) Weeratunga G, Kumar V. Phytochemistry 1985;24:2369-2372. (f) Kubo I, Fukuhara K. J. Nat. Prod 1990;53:968-971. (g) Tsanuo MK, Hassanali A, Jondiko IJO, Torto B. Phytochemistry 1993;34:665667.

5. (a) Kupchan SM, Uchida I, Shimada K, Fei BY, Stevens DM, Sneden AT, Miller RW, Bryan RF. J. Chem. Soc. Chem. Comm 1977:255-256. (b) Shimada K, Nambara T, Uchida I, Kupchan SM. Heterocycles 1979;12:1445-1448. (c) Anjaneyulu ASR, Rao MN. Indian J. Chem., Sect B 1980;19B: 944-949. (d) Shimada K, Kyuno T, Nambara T, Uchida I. Heterocycles 1981;15:355-360. (e) Shimada K, Kyuno T, Nambara T, Uchida I. Chem. Pharm. Bull 1982;30:4075-4081. [PubMed: 7165878] (f) Shimada K, Kyuno T, Nambara T, Uchida I. Phytochemistry 1985;24:1345-1350. (g) Shimada K, Ishii N, Ohishi K, Ro JS, Nambara T. J. Pharmacobio-Dyn 1986;9:755-759. [PubMed: 3025406] (h) Shimada K, Masuda H, Ohtaki H, Kobayashi N, Nambara T. Heterocycles 1990;30:441-450. (i) Tsujino Y, Ogoche JIJ, Tazaki H, Fujimori T, Mori K. Phytochemistry 1995;40:753-756. (j) Kasai HF, Kawai K, Shimada K. Heterocycles 2000;53:2689-2700.

6. Pauli GF, Matthiesen U, Fronczek FR. Phytochemistry 1999;52:1075-1084.

7. (a) Hoffmann JJ, Cole JR. J. Pharm. Sci 1977;66:1336-1338. [PubMed: 903878] (b) Hembree JA, Chang CJ, McLaughlin JL, Peck G, Cassady JM. J. Nat. Prod 1979;42:293-298. (c) Koike K, Bevelle C, Talapatra SK, Cordell GA, Farnsworth NR. Chem. Pharm. Bull 1980;28:401-405. [PubMed: 7389015] (d) Wagner H, Habermeier H, Schulten HR. Helv. Chim. Acta 1984;67:54-64. (e) Kamano 
Y, Sato N, Nakayoshi H, Pettit GR, Smith CR. Chem. Pharm. Bull 1988;36:326-332. [PubMed: 2837339] (f) Kaneda N, Chai H, Pezzuto JM, Kinghorn AD, Farnsworth NR, Tuchinda P, Udchachon J, Santisuk T, Reutrakul V. Planta Med 1992;58:429-431. [PubMed: 1470666] (g) Baek NI, Lee YH, Park JD, Kim SI, Ahn BZ. Planta Med 1994;60:26-29. [PubMed: 8134412] (h) Decosterd L, Gustafson KR, Cardellina JH II, Cragg GM, Boyd MR. Phytotherapy Res 1994;8:74-77. (i) Gil RR, Lin L-Z, Chai H-B, Pezzuto JM, Cordell GA. J. Nat. Prod 1995;58:848-856. [PubMed: 7673928] (j) Kitanaka S, Takido M, Mizoue K, Nakaike S. Chem. Pharm. Bull 1996;44:615-617. [PubMed: 8882460] (k) Kiuchi F, Fukao Y, Maruyama T, Obata T, Tanaka M, Sasaki T, Mikage M, Haque ME, Tsuda Y. Chem. Pharm. Bull 1998;46:528-530. [PubMed: 9549894] (1) Ankli A, Heilmann J, Heinrich M, Sticher O. Phytochemistry 2000;54:531-537. [PubMed: 10939358] (m) Laphookhieo S, Cheenpracha S, Karalai C, Chantrapromma S, Rat-a-pa Y, Ponglimanont C, Chantrapromma K. Phytochemistry 2004;65:507-510. [PubMed: 14759549] (n) Cheenpracha S, Karalai C, Rat-a-Pa Y, Ponglimanont C, Chantrapromma K. Chem. Pharm. Bull 2004;52:1023-1025. [PubMed: 15305009] (o) Roy MC, Chang F-R, Huang H-C, Chiang MY-N, Wu Y-C. J. Nat. Prod 2005;68:1494-1499. [PubMed: 16252914] (p) Lhinhatrakool T, Sutthivaiyakit S. J. Nat. Prod 2006;69:1249-1251. [PubMed: 16933890]

8. Hanada R, Abe F, Mori Y, Yamauchi T. Phytochemistry 1992;31:3547-3551.

9. Kamel MS, Assaf MH, Abe Y, Ohtani K, Kasai R, Yamasaki K. Phytochemistry 2001;58:537-542. [PubMed: 11576593]

10. Cao S, Brodie PJ, Randrianaivo R, Ratovoson F, Callmander M, Andriantsiferana R, Rasamison VE, Kingston DGI. J. Nat. Prod.

11. Louie KG, Behrens BC, Kinsella TJ, Hamilton TC, Grotzinger KR, McKoy WM, Winker MA, Ozols RF. Cancer Res 1985;45:2110-2115. [PubMed: 3986765]

12. Cao S, Norris A, Miller JS, Ratovoson F, Razafitsalama J, Andriantsiferana R, Rasamison VE, TenDyke K, Suh T, Kingston DGI. J. Nat. Prod 2007;70:361-366. [PubMed: 17263578] 


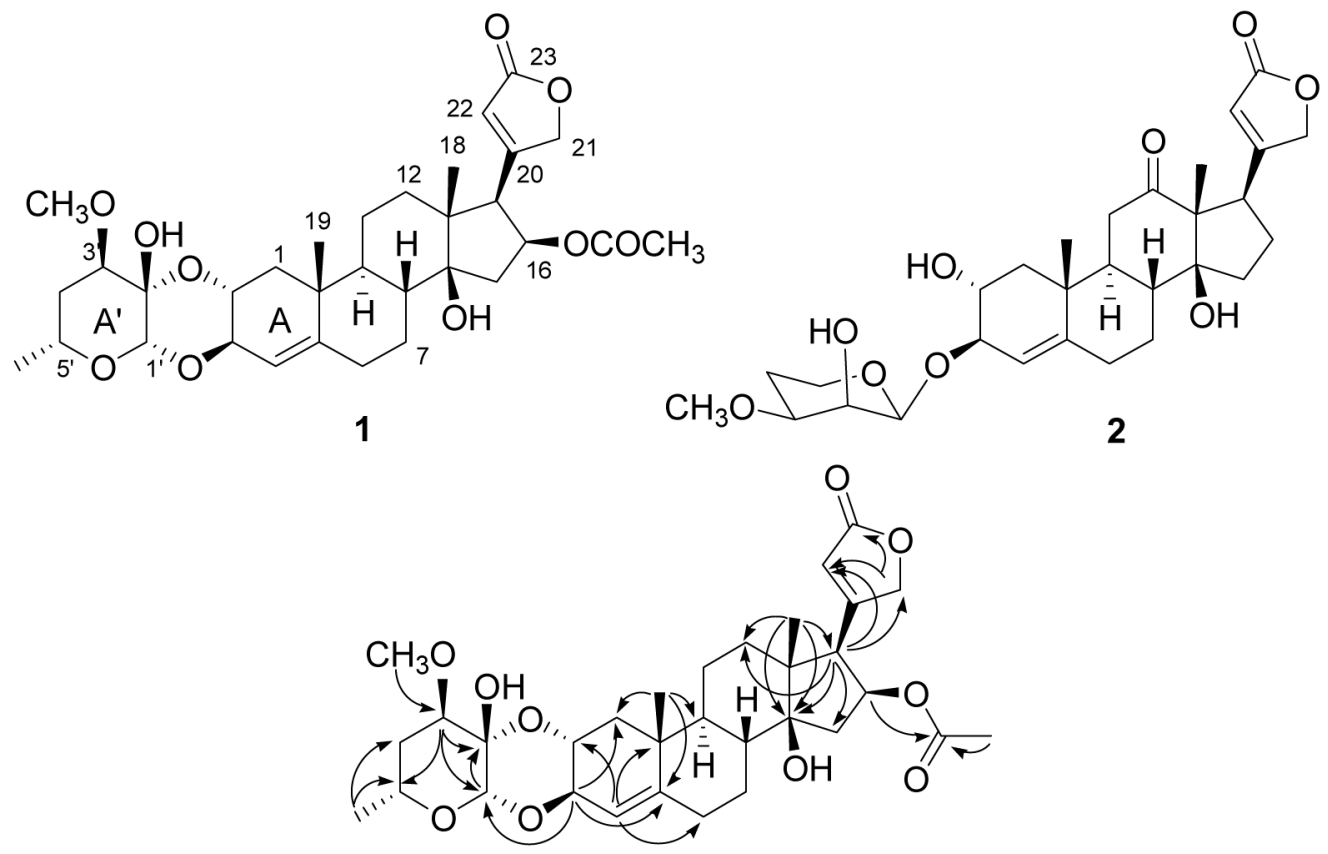

Figure 1.

Key HMBC correlations of $\mathbf{1}$ 


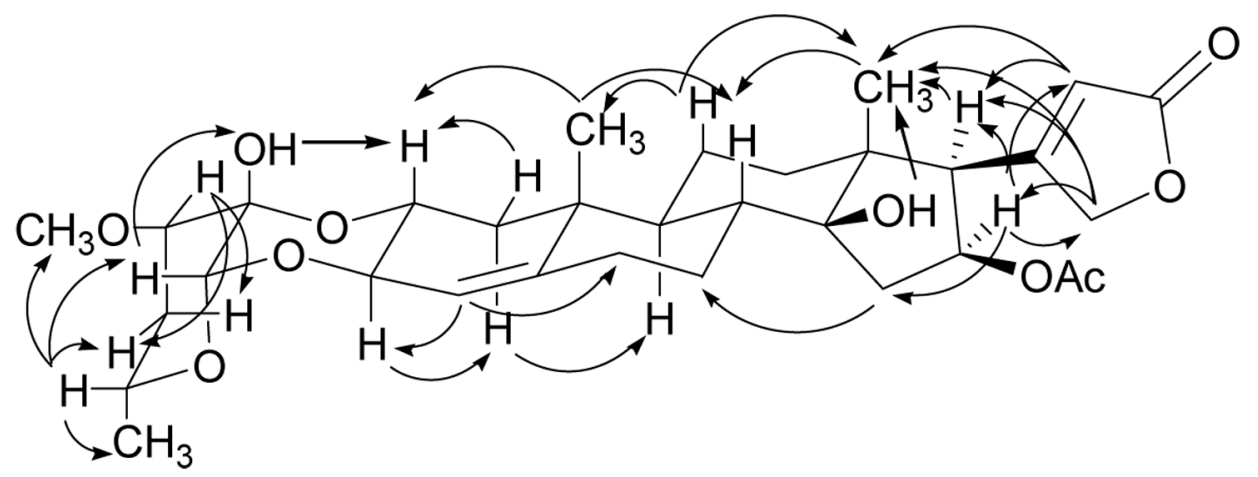

Figure 2.

Key ROESY correlations of 1 


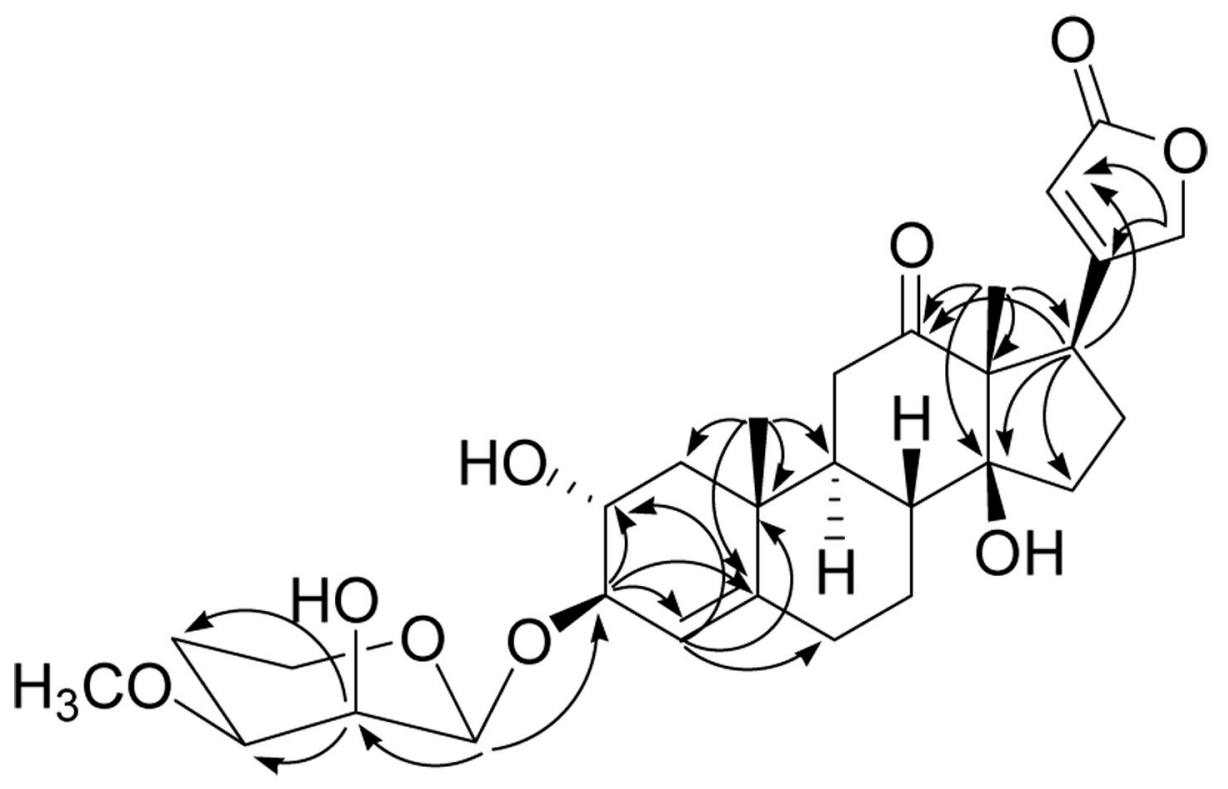

Figure 3.

Key HMBC correlations of 2 


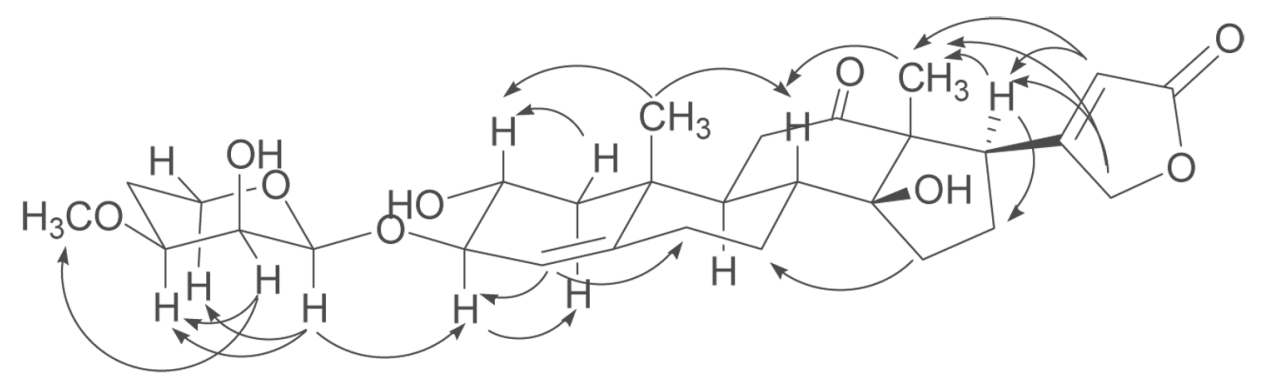

Figure 4.

Key ROESY correlations of $\mathbf{2}$ 


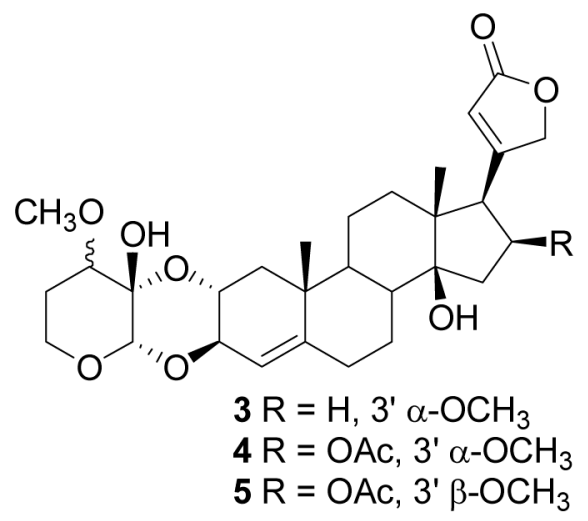

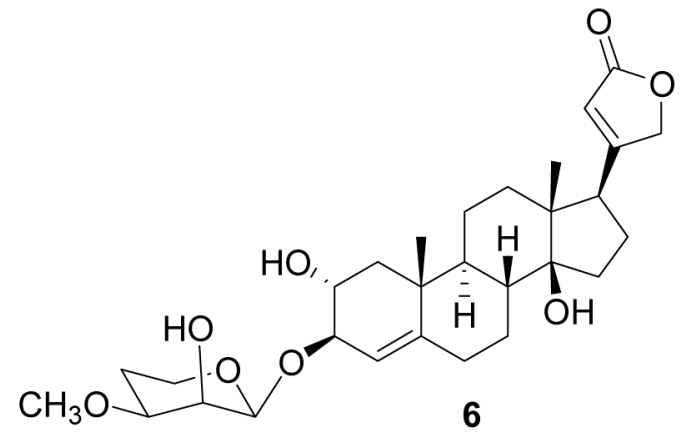

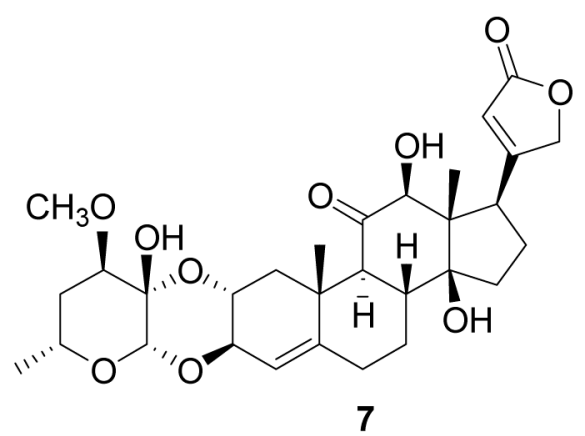

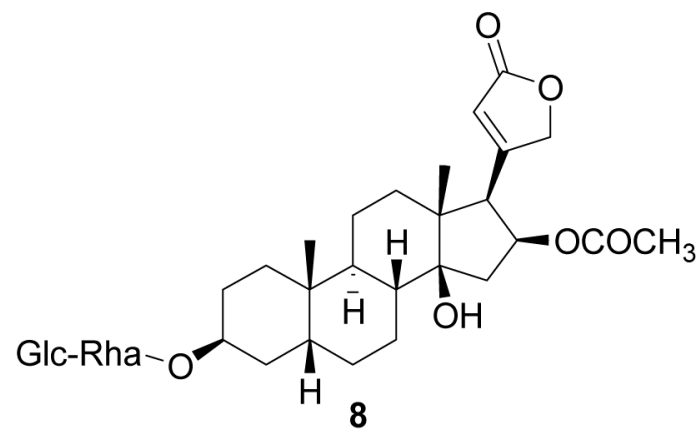




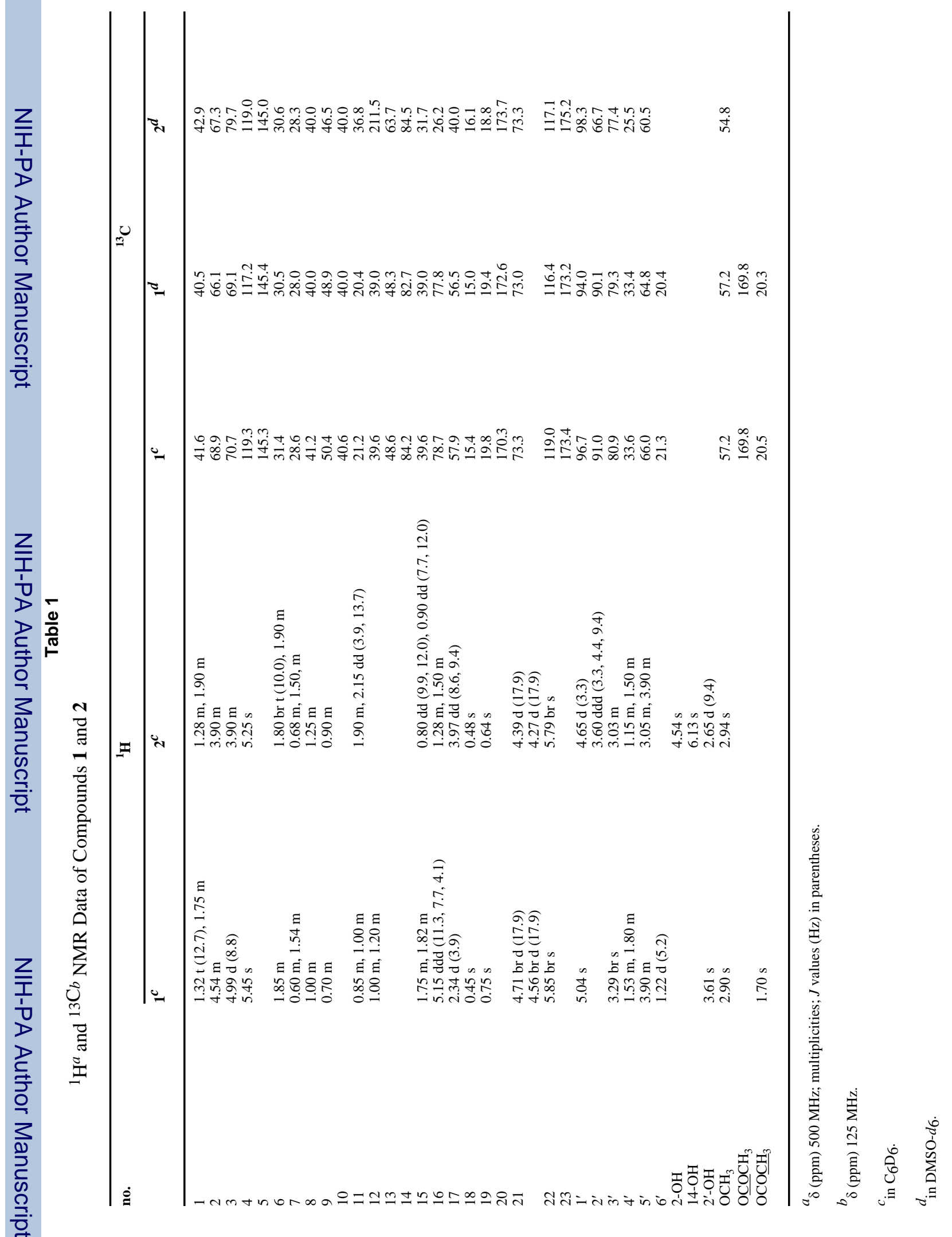




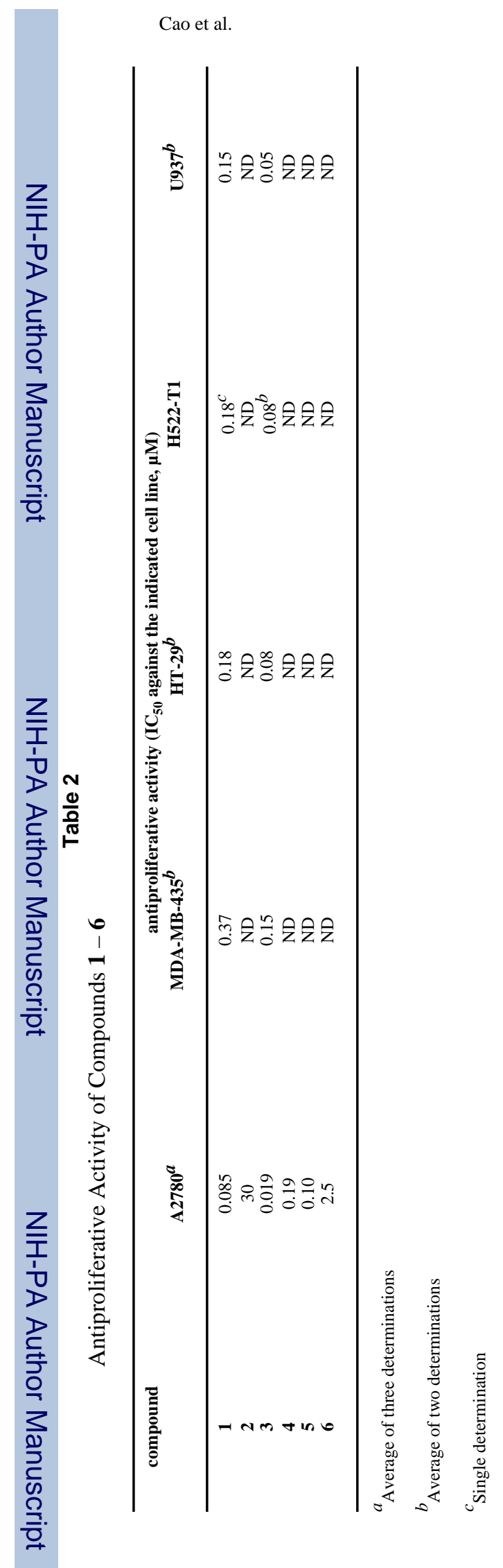

J Nat Prod. Author manuscript; available in PMC 2008 July 14. 